\title{
Infancia y temporalidades queer en la Galería del Rojas ${ }^{1}$
}

Francisco Lemus

Universidad Nacional de Tres de Febrero - CONICET

\section{Resumen}

El presente trabajo explora la producción artística de Marcelo Pombo, Fernanda Laguna y Omar Schirilo, artistas nucleados en el Centro Cultural Rector Ricardo Rojas de la ciudad de Buenos Aires durante los años noventa, a través de operaciones plásticas, materiales, contenidos y referencias visuales vinculadas a la infancia como modo político de interferir con la normatividad y con las ficciones normativas que regulan el canon artístico. Mediante estas ideas, se pensarán las imagénes a partir de los reordenamientos estéticos y políticos provistos por las temporalidades queer.

Palabras clave: Centro Cultural Rector Ricardo Rojas; arte; infancia; temporalidades queer

\begin{abstract}
This paper explores the works of art by Marcelo Pombo, Fernanda Laguna and Omar Schiliro, artists working in the Centro Cultural Rector Ricardo Rojas in Buenos Aires during the 1990's. Their plastic operations, materials, contents and visual references are related to childhood as a political way of interfering with heteronormativity and normative fictions that regulate the artistic canon. Through these ideas, we will think of the images from the aesthetic and political rearrangements that provide queer temporalities.
\end{abstract}

Key words: Centro Cultural Rector Ricardo Rojas; art; childhood; queer temporalities

${ }^{1}$ Este trabajo forma parte del proyecto doctoral "Imágenes disidentes. Artes visuales y formas de subjetivación gay (1989-1997)", desarrollado gracias a una beca interna doctoral de CONICET radicada en el Instituto de Investigación en Arte y Cultura "Dr. Norberto Griffa" (Universidad Nacional de Tres de Febrero) y, también, del proyecto de investigación "Genealogías críticas de las desobediencias sexuales desde el sur", dirigido por el Lic. Fernando Davis en el Laboratorio de Investigación y Documentación en Prácticas Artísticas Contemporáneas y Modos de Acción Política en América Latina (Facultad de Bellas Artes de la Universidad Nacional de La Plata). Agradezco a Fernanda Laguna, Marcelo Pombo y Jorge Gumier Maier el derecho de reproducción de las imágenes. 
Durante los años noventa, las curadurías de Jorge Gumier Maier (1953-) redefinieron los parámetros del arte contemporáneo en el campo artístico de Buenos Aires al establecer una estética trazada por formas de subjetivación sexo-disidentes, la adscripción a procedimientos degradados por un canon masculino y heterosexual — como las artesanías y las manualidades-y la apropiación de elementos de la cultura de masas y el arte popular, por lo general, en los códigos del camp. Este proceso tuvo como epicentro la Galería de Artes Visuales del Centro Cultural Rojas, dependiente de la Universidad de Buenos Aires, que Gumier Maier dirigió entre 1989 y $1996 .{ }^{2}$ Gumier Maier delineó su programa de exposiciones a través de la incorporación de artistas no profesionalizados, outsiders y artesanos, y del interés por propuestas artísticas que circulaban por fuera de las esferas legítimas del arte, como el arte terapia y la educación artística no formal.

Si bien las trayectorias artísticas vinculadas al Rojas resultan disímiles, en artistas como Marcelo Pombo (1959-), Fernanda Laguna (1972-) y Omar Schiliro (1962-1994) encontramos lugares de enunciación que apelan a la infancia o, mejor dicho, a la construcción de un yo artístico ligado al inestable pasaje entre la niñez y la adolescencia; una caja de herramientas maleables a través de la cual embellecieron objetos y generaron imágenes devocionales, incluso de fan, inmersas en una temporalidad alternativa, queer, no lineal y progresiva. Un tiempo diferencial que, en los términos de Judith Halberstam, podemos pensar a través de modos de organización no normativos de comunidad, identidad sexual y el desarrollo de estéticas y políticas por fuera de los marcos regulatorios de las instituciones de la intimidad burguesa. ${ }^{3}$

A partir de estas ideas, el presente trabajo indaga en las operaciones, materiales, temas y referencias que integran las obras de estos artistas, para poder pensar formas en las que lo infantil, como señala Cynthia Francica, se proyecta como un espacio de potencialidades exento de la productividad que gobierna la adultez. En este sentido, sostenemos que Pombo, Schiliro y Laguna produjeron desde la agencia con esferas contrapúblicas, es decir, a través de la pertenencia y el diálogo con públicos de estatus subordinado que, según Michael Warner, son generados por

${ }^{2}$ Ubicado en el barrio de Balvanera, el Centro Cultural Rector Ricardo Rojas (1984), es una institución que integra la Secretaría de Extensión de la Universidad de Buenos Aires. Durante la apertura democrática y la década de los noventa, en el Rojas tuvieron lugar experiencias artísticamente radicales, donde no solo se destacó el área de artes visuales —junto a la creación de la Fotogalería (1995) dirigida por Alberto Goldenstein-, sino también las áreas de artes escénicas y literatura y, más adelante, las áreas queer y de tecnologías de género. El Clú de Clan, Batato Barea, Alejandro Urdapilleta, Humberto Tortonese, Las Gambas al Ajillo, Tamara Kamenzsain, Rubén Szuchmacher, Vivi Tellas, Alejandro Tantanian, María Moreno, Naty Menstrual, Susy Shock, son algunxs de Ixs artistas, músicxs, escritorxs y dramaturgxs que han transitado por el centro cultural. En cuanto a la galería es necesario señalar que, en sus comienzos, sus condiciones de infraestructura fueron bastante precarias a causa del escaso presupuesto para gastos de producción. Incluso, vale mencionar las tensiones ocurridas al interior del Rojas, como por ejemplo la destrucción de obras por parte del personal y la pintada homófoba - "fuera putos del Rojas" - durante la exposición Harte Pombo Suárez (1989) (Gumier Maier, entrevista personal, 12 Mar. 2013).

3 A través de coordenadas similares a las de Judith Halberstam, Elizabeth Freeman sostiene que las temporalidades queer poseen la capacidad de generar patrones temporales en torno a lo imprevisible: formas no secuenciales de tiempo que involucran prácticas artísticas, estados de ensueño y otras experiencias que, en ocasiones, no forman parte del umbral de registro del historicismo. 
sujetos cuyos horizontes van más allá de las representaciones de género y sexualidad, ya que posibilitan la creación de mundos culturales y relaciones sociales en las que se asocian lo íntimo, los afectos y las prácticas eróticas y artísticas. ${ }^{4}$

\section{El modelo doméstico de Gumier Maier}

Antes de adentrarnos en el análisis de las producciones del Rojas, resulta necesario situarlas históricamente para pensar sus condiciones de posibilidad en el entramado político y cultural de los años noventa. Anticipado a los plazos constitucionales y ante una fuerte crisis social y económica, el 8 julio de 1989 el presidente por la Unión Cívica Radical, Raúl Ricardo Alfonsín, entregó su mando al candidato electo por el Frente Justicialista Popular, el peronista Carlos Saúl Menem (1989-1999). La efervescencia democrática y los anhelos de un estado que recompusiera los lazos sociales entre ciudadanía y aparato político quedaban truncos. Días más tarde era inaugurada la Galería de Artes Visuales del Rojas bajo la gestión de Jorge Gumier Maier. ${ }^{5}$ Ávido con las palabras, el artista y curador había publicado un mes antes, en La Hoja del Rojas, "Avatares del arte". Seis ítems, en una carilla similar a un manifiesto, bastaron para desplegar sus ideas acerca de la escena artística: la pintura como desleída y sucia y el rechazo del arte categorizado como "político". Tanto en esta primera intervención como en el desarrollo del programa de exposiciones, se observa un desplazamiento táctico al interior de un campo que comenzaba a configurarse bajo las políticas culturales del neoliberalismo. Si bien a lo largo del tiempo las curadurías de la Galería del Rojas se diversificaron, en líneas generales es posible señalar que el modelo de Gumier Maier implicó una apuesta por artistas que no contaban con visibilidad en los años ochenta, ya sea por su joven edad o por la ausencia de un capital social ligado al mundo del arte.

En contraposición al incipiente y fugaz internacionalismo de los años ochenta, dado por la pintura de gran escala, las conferencias de Achille Bonito Oliva, la representación nacional en bienales y la resonancia de un pintor como Guillermo Kuitca, en el Rojas se exhibieron formalismos exacerbados que revisitan el modernismo de manera desviada y rozan lo camp; objetos pequeños, cotidianos y artesanales, ornamentados de manera austera o barroca; piezas textiles hechas con técnicas asignadas por la heteronorma a las mujeres; esculturas blandas y suaves con tela de peluche, collages y dibujos con imágenes provenientes de la pornografía gay y revistas semanales, pinturas y maquetas en estrecha filiación con el imaginario del cómic, etcétera. Más adelante, el auge de un lenguaje como el neoconceptualismo, ${ }^{6}$ caracterizado por las instalaciones, la inmaterialidad y el

${ }^{4}$ No solo Michael Warner ha indagado en el concepto de "contrapúblicos"; los aportes de José Esteban Muñoz a partir de la publicación de Desidentifications (1999), resultan centrales para entender este concepto. Según Muñoz, las esferas contrapúblicas resultan cadenas relacionales de resistencia que desafían el modelo liberal de las esferas públicas burguesas y heteronormativas.

5 Durante la transición democrática, Gumier Maier se desempeñó como periodista en las revistas independientes El Porteño, Cerdos y peces y Fin de Siglo. En años anteriores, había participado de la política universitaria en la izquierda maoísta y también formó parte del Grupo de Acción Gay (1983-1985).

${ }^{6}$ En consonancia con las nuevas cartas de ciudadanía generadas por el multiculturalismo — signo del asimilacionismo neoliberal de la diferencia-, un nuevo internacionalismo artístico fue propagado desde los 
archivo, será motivo de divergencias en los textos y apariciones de Gumier Maier, quien pregonaba una estética radicalmente opuesta.

En un principio, la presidencia de Menem debió anteponerse al fuerte proceso hiperinflacionario que atravesaba el país; como salida introdujo una serie de reformas neoliberales, entre ellas la privatización acelerada de empresas estatales. De puertas afuera el país se alineó con los mandatos internacionales, avalando un supuesto crecimiento económico, mientras que al interior el avance del capital extranjero comenzó a imponer sus reglas, en especial sobre la sociedad de trabajo. Para la socióloga Maristella Svampa, la imagen de un Estado postrado, incapaz de garantizar la moneda -como sucedió durante el alfonsinismo-, permitió el desarrollo de políticas consensuadas que, poco a poco, encausaron al país hacia una sociedad configurada bajo el signo de la exclusión. ${ }^{7}$ Las privatizaciones y la concentración mediática posibilitaron la conformación de un discurso hegemónico en manos de los grandes grupos económicos beneficiados por el menemismo, que avaló las políticas implementadas y el desarrollo de un clima cultural configurado por el capitalismo (Wortman).

Farandulización de la política, extranjería acrítica, shoppings, fitness y new age, constituyeron una dinámica de relaciones atravesadas no solo por el corrimiento de lo público como garante de derechos, sino también por la modelación liberal de los sujetos, en la cual la meritocracia y la estrecha vinculación con los objetos de consumo dieron cauce a un optimismo idealizado que, como correlato, tendió a reproducir la desigualdad social y a volver normativos los afectos generados en torno al progreso. 8 En esta coyuntura, el campo artístico experimentó la consolidación de los espacios expositivos creados en los años ochenta, la reactualización de otros de larga data a través del apoyo de esferas empresariales, la apertura de fundaciones y premios provenientes del capital financiero y la creación de talleres de formación artística, casi siempre, subsidiados desde el exterior. ${ }^{9}$ Las transformaciones ocurridas propiciaron la circulación y

centros cíclicos de poder: el neoconceptualismo. En palabras de Inés Katzenstein, "una plataforma capaz de absorber e integrar las diferencias culturales que entraban en escena" y un "patrón de traducción de las diversas identidades que se encontraban en los espacios de conexión cosmopolitismo" (34).

${ }^{7}$ Siguiendo a Eduardo Basualdo, es necesario remarcar que esta imagen fue creada en los primeros años de la Convertibilidad (1991-1994), cuyo resultado inmediato fue la salida de la crisis (interrupción de la inflación y expansión del PBI sobre la expansión del consumo interno y una creciente inversión), éxito que instauró rápidamentela creencia —ideada por los sectores dominantes-de un Estado distribucionista nocivo para el crecimiento económico.

${ }^{8}$ A través de las lecturas El corazón de una nación (2011) y Cruel Optimism (2011) de Lauren Berlant, Cecilia Macón señala que "Berlant despliega detalladamente la tesis de que el mantenimiento de las fantasías de progreso, principalmente las de movilidad social ascendente, constituyen un afecto particular: el optimismo cruel, una suerte de operación ideológica dedicada a que las personas se mantengan apegadas a vidas que, en los hechos, no resultan en su felicidad" (21-22).

${ }^{9}$ Me refiero a espacios como el Centro Cultural Recoleta (1980), el Instituto de Cooperación Iberomaericana (1988), el Museo Nacional de Bellas Artes, durante la gestión de Jorge Glusberg (1994-2003), la Fundación Banco Patricios (1990), la Fundación Antorchas (1985-2006), los premios Fundación Amalia Lacroze de Fortabat (1988) y Fundación Eduardo F. Costantini (1995) y también la apertura de la feria Arteba (1991). 
legitimación de los artistas del Rojas, quienes adquirieron notoriedad no solo en la prensa gráfica, sino también en el mercado artístico local.

"¡El poeta no trabaja!", dijo Gumier Maier ("Abajo el trabajo" 23) al citar a Arthur Rimbaud en una conferencia que presentaba interrogantes sobre la profesionalización del artista en las agendas globales. A diferencia de este proceso, el "modelo doméstico", como lo señaló el curador en otra oportunidad ("El tao del arte" 8), dio lugar a la construcción de un tipo de artista outsider, artesano, incluso, similar a una maestra de manualidades. La posibilidad de descanso y ocio propone una metáfora que complejiza la irrupción de la Galería de Rojas: lejos de caer en un juicio romántico, Gumier Maier no abogó por un tipo de vagancia inspiracional, sino por una producción artística en alianza con los trabajadores no reconocidos formalmente — desde un artesano caído del mapa de la modernidad industrial, pasando por una ama de casa hasta llegar a los jóvenes-; estos ocupan un lugar degradado, administrable por la biopolítica y exotizante en las representaciones de la cultura. De esta manera, instaló el placer por la forma caprichosa, lo pobre y las expresiones que escapan del estatuto autónomo del arte al tomar las trivialidades de las que hacen arte en los contornos ficcionales de la división del trabajo. Una actitud que desterritorializa la sexualidad y desvía las categorías a través de producciones que tensan o invierten los usos y costumbres generizados por las ficciones normativas de la cultura.

Teniendo en cuenta la visibilidad de estos artistas, es necesario resaltar otros efectos en torno a la recepción por parte de la crítica de arte. En un texto titulado "El absurdo y la ficción en una notable muestra" (1992), Jorge López Anaya ${ }^{10}$ dio cuenta del arte de una época de "levedad generalizada", utilizando la palabra light — sin ninguna connotación peyorativa - para definir las obras de Gumier Maier, Alfredo Londaibere, Benito Laren y Omar Schiliro expuestas en el Espacio Giesso de Buenos Aires. Para López Anaya, los artistas realizaban una crítica desde lo irónico, lo grotesco, los ritos cotidianos y lo leve. Recuperación del mal gusto, kitsch y sexualidad, fueron sus recursos para definir un "efecto de realidad", una simulación que podía "nutrir" al arte contemporáneo. A diferencia de otras reseñas, esta vez el crítico intentó actualizarse con algunas lecturas de la posmodernidad, ${ }^{11}$ advirtiendo una disposición estética hacia el kitsch y señalando tímidamente las marcas sexo-genéricas de las obras. Sin embargo, como señala Valeria González, "el significante light se mostró de inmediato capaz de expresar y aglutinar los descontentos y rivalidades en el medio" (17).

Sobre la conformación de espacios expositivos en la década del noventa, véase Pineau.

${ }^{10}$ Historiador y crítico de arte, López Anaya ejerció la docencia en la Facultad de Bellas Artes de la Univer sidad Nacional de La Plata y en la Facultad de Filosofía y Letras de la Universidad de Buenos Aires. Colaboró con diarios y revistas como La Nación, Lápiz y Art Nexus.

${ }^{11}$ Como demuestra la estrecha relación de sus palabras con las ideas desarrolladas por Fredric Jameson en El posmodernismo o la lógica cultural del capitalismo avanzado (1991) y James Baudrillard en Cultura y simulacro (1978) y La guerra del Golfo no ha tenido lugar (1991). A su vez, teniendo en cuenta el clima cultural de la época, es necesario señalar la cercanía con El hombre light (1992) de Enrique Rojas, un libro de autoayuda de gran divulgación. 
La charla "Arte light" en el marco del ciclo "¿Más allá de toda duda?" (1993), organizado por Marcia Schvartz, Felipe Pino y Duilio Pierri en el Centro Cultural Rojas, ejemplifica estas polaridades. En la transcripción del encuentro se observan las divergencias entre los integrantes de la mesa -Omar Schiliro, Juan José Cambre, José Garófalo y Marcelo Pombo-, los organizadores y algunos artistas presentes como Ricardo Longhini, León Ferrari y la crítica Lelia Driben. Pombo y Schiliro señalaron que trabajaban desde el embellecimiento de objetos y la intimidad, mientras que otros debatieron sobre el tratamiento de lo "superficial", el carácter de denuncia que debería asumir el arte y el peso de la ideología en la obra de arte. Gumier Maier, también en el público, manifestó sus sospechas respecto a los posicionamientos más rancios y declaró: "Para los que inventaron este término arte rosa light $o$, arte puto, si no se animan a decirlo, que expliquen qué es este arte y que digan si creen que el arte se ha putizado" (Ameijerias "Un debate sobre las características del supuesto arte light" 122). Estas mismas ideas las retomó en el texto de la exposición El Tao del Arte (1997), en el cual propuso pensar el "arte rosa light" como una estrategia eficaz para soslayar la presencia del "maricón" en las artes visuales.

A través de un tono virulento, el artículo "Arte guarango para la Argentina de Menem" (1995), publicado por Pierre Restany en la revista Lápiz, relacionó el estilo de vida de la clases altas menemistas con las producciones de artistas vinculados al Rojas. "Guarango", término popular sinónimo de grosero, vulgar, "invertido cultural" y también "invertido sexual", ${ }^{12}$ funcionó en sus palabras como un modo de nombrar y degradar los consumos culturales y las expresiones artísticas vinculadas a las mujeres, las maricas y los sectores populares. Mediante esta retórica se observa lo eficaz que resulta esa vieja división, señalada por Andreas Huyssen (2002), entre el modernismo y la cultura de masas asociada a "lo femenino" y, por lo tal, devaluada. Subtexto oculto y espectro que visita el modernismo, la cultura de masas y la consecuente regeneración de un arte popular ocuparon el lugar de la regresión frente a la progresión de la superioridad masculina, configurada tanto por su distinción aristocrática como por su filiación revolucionaria. En un contexto en el cual el posmodernismo funcionó como sitio enunciativo de las negociaciones entre el arte elevado, la cultura de masas y la cultura de lo cotidiano, la tradicionalidad de algunos actores del escenario local y la ausencia de un pensamiento crítico sobre el arte contemporáneo hicieron de lo light una imagen negativa. Un modo de eufemización injurioso que, en su carácter performativo, incorporó un sinfín de estéticas desvalorizadas.

${ }^{12}$ Según José Ramos Mejía, autor del estudio Las multitudes argentinas, publicado en 1899, el "guarango" es un "invertido cultural" similar a los "invertidos de instinto sexual". En sus palabras, "se parece a los invertidos del instinto sexual que revelan su potencia dudosa por una manifestación atrabiliaria de los apetitos. Necesita de ese color vivísimo, como el erotómano del olor intenso de la carne; quiere las combinaciones bizarras y sin gusto de las cosas, como éste de las actitudes torcidas y de los procedimientos escabrosos, para satisfacer especiales idiosincrasias de su sensibilidad" (214). También Sylvia Molloy aborda la figura finisecular del "guarango". 


\section{Artesanit*s queer}

En un exhaustivo trabajo que analiza las vertientes del giro afectivo y su desarrollo en los estudios de género y la teoría queer, Cecilia Macón señala que la temporalidad queer, en su interferencia con el tiempo total, puede "dar cuenta del deseo y la fantasía, dos atributos afectivos centrales para el despliegue de modos alternativos de pensar la imaginación histórica y la agencia" (25). Al momento de indagar en las imágenes producidas por Marcelo Pombo, Fernanda Laguna y Omar Schiliro, nos encontramos con operaciones articuladas a través del trabajo artesanal y las manualidades, que incluyen referencias a la infancia y la adolescencia: situaciones de fantasía y experiencias reales que presentan una disposición subjetiva a afectos alegres y tristes y al deseo por fuera de la norma. Obras en las que se superponen distintos tráficos visuales de un ritmo que no es el de la moda, ni el de las narrativas épicas y centradas, sino el de relatos íntimos y minoritarios generados en espacios reducidos que a su vez sortean los marcos contenedores de lo identitario y las prerrogativas de una normalidad ampliada. En este sentido, nos interesa atender a aquellas formas de lo queer en las cuales lo infantil funciona como una imagen contraproductiva que habilita a desviarse de las trayectorias lineales y reproductivas que configuran tanto los destinos personales como los profesionales (Francica).

La artesanía es una práctica que traza comunidad, no solo porque lo autoral es dejado de lado por lo colectivo, sino porque el rol de los artesanos es producir para fines comunes. Experimentación en un tiempo propio, anacronismo y autonomía creativa frente a la progresión de otras prácticas, son algunas de las características del trabajo artesanal, aspectos que contrastan con la modernidad y la distinción aristocrática del arte. ${ }^{13}$ Desde un desplazamiento aún más bastardo, las manualidades también comparten algunos de estos elementos, a excepción de que están hechas desde una comunidad que es un contrapúblico. Para Michael Warner, los contrapúblicos son un público de estatus subordinado, integrado tanto por amigos como por desconocidos en vías de comunalidad, ya que posibilita la creación de mundos culturales y relaciones sociales en los cuales se asocian lo íntimo, los afectos, estilos de corporalidad, las prácticas eróticas y pedagógicas, los discursos, las experiencias artísticas, etcétera. Es decir, los contrapúblicos funcionan como escenas multicontextuales "de asociación y de identidad que transforman las vidas privadas que median" (64) al imaginar formas de sociabilidad y reflexión que generan interpretaciones oposicionales a los públicos dominantes y permiten el desarrollo de subjetividades por fuera de las convenciones sociales y culturales. ${ }^{14}$ De este modo, propongo leer tanto las trayectorias biográficas como las

${ }^{13}$ Richard Sennett propone pensar la artesanía como un saber corporal del capital social, es decir, conocimientos y habilidades que se van acumulando y transmitiendo en la interacción social.

${ }^{14}$ Warner analiza la definición de los públicos racionales-críticos de Jürgen Habermas en The Transformation of the Public Sphere (1989) y la distinción que realiza Hannah Arendt —La condición humana (1958)—, entre la "actividad pública [...] como marco de referencia común de interacción que se necesita para permitir tanto un mundo compartido de iguales como la revelación de la agencia única" (66) y lo privado fusionado en la vida familiar, que según Arendt resulta inapropiado para la política ya que no contaría con la configuración creativa de la vida pública. A su vez, Warner se refiere también a la definición de contrapúblicos esbozada por Nancy Fraser, "espacios discursivos paralelos en los cuales los miembros de grupos sociales 
obras de estos artistas a través de un público conformado por niños, maricas, maestras, artesanos, amas de casa, adolescentes, fans, cantantes, divas apropiadas por el camp y otros personajes subculturales.

A comparación de otros artistas, Pombo, Laguna y Schiliro poseen una formación autodidacta, gestada entre los saberes domésticos y escolares, las viejas pinacotecas de algún aparador, profesiones y oficios aprendidas para sobrevivir, modelaciones disidentes y formas de agencia que despertaron el interés por expresiones culturales descentradas; proyecciones que en los casos de Pombo y Laguna tuvieron lugar en el activismo sexual y la autogestión. Al analizar sus obras encontramos fallas, asociaciones caprichosas, relatos desordenados y ensamblajes sin jerarquías, en las cuales las entradas y salidas a las esferas contrapúblicas y el trabajo manual — por su pertenencia subalterna - conllevan una relación crítica con la autoridad.

Marcelo Pombo posee una vasta producción iniciada con dibujos realizados en San Pablo durante los tempranos años ochenta. En estas imágenes un grupo de animales adquiere rasgos humanos $y$ asume comportamientos sexuales excéntricos que traspasan los límites de las metáforas diseñadas sobre la alteridad. Más tarde, realizó una serie de envases decorados de manera modesta con moñitos y adhesivo vinílico y también ornamentados estilo vegetal. En la actualidad, el artista crea pinturas e imágenes digitales con apropiaciones retorcidas del arte latinoamericano y argentino, indagando en los contornos y lagunas provinciales del canon. Proveniente de una familia de clase media empobrecida, sin estudios formales en arte, profesor

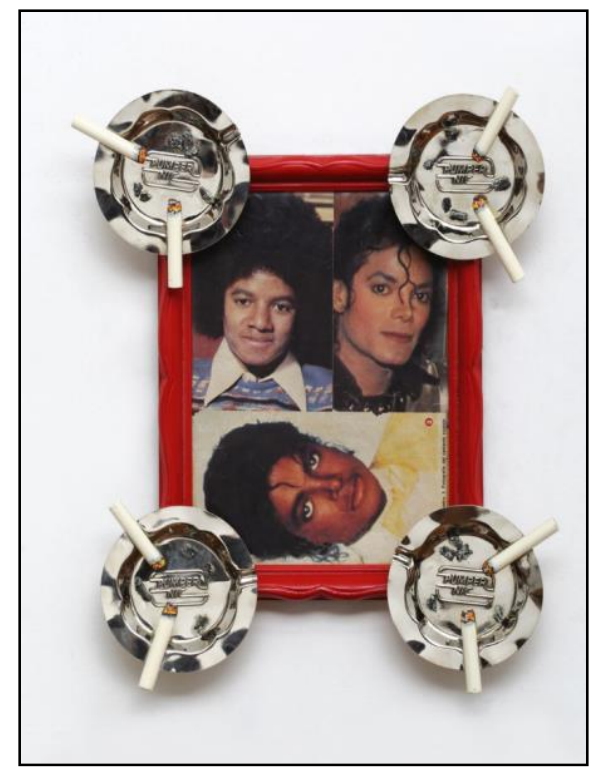

Marcelo Pombo, Michael y yo, 1989. de enseñanza especial y activista del Grupo de Acción Gay, ${ }^{15}$ Marcelo Pombo trabaja como un artesano del lujo barato, a veces con algo de perversión y, otras, como un decorador compulsivo. En sus operaciones ensambla, decora y se obsesiona con el esmalte (barrido y gota sobre gota), el photoshop y la web como un archivo pirata al que ingresa para conseguir la imagen indicada que calce con su vocación por lo popular y lo anacrónico.

subordinados inventan y echan a circular contradiscursos para formular interpretaciones oposicionales de sus identidades, intereses y necesidades" (138). Véase también Fraser.

${ }^{15}$ El Grupo de Acción Gay (GAG) fue un grupo de activismo sexo-disidente integrado por Gumier Maier, Carlos R. Luis, Oscar Gómez, Marcelo Pombo, Gustavo Gelmi, Facundo Montenegro, Julio Olmos y Alejandro Kantemiroff, entre otros. Desarrolló su actividad entre 1983 y 1985, tiempo en el que publicó los únicos dos números de la revista Sodoma (1984-1985) —el primero con ilustraciones de Gumier Maier y el segundo con dibujos y collages de Pombo-, además de realizar diferentes actividades como volanteadas y manifestacionesjunto a la Comunidad Homosexual Argentina (CHA) y otros grupos más pequeños, como el Grupo Federativo Gay (Cuello y Lemus 2016). 
Entre sus obras tempranas encontramos Michael y yo (1989), collage compuesto por tres fotografías de revista que exhiben las transformaciones faciales de Michael Jackson, y Xuxa (1993), realizada con un panel decorado como los carteles realizados por los niños que visitaban el programa televisivo de la animadora pero más extravagante, con esmalte, stickers, flecos y la leyenda "Xuxa estás en mi mente y mi corazón, Marcelo". Estas obras dan cuenta de un adolescente cholulo de ídolos infantiles y juveniles, cuya extensión a la adultez conforma un repertorio sin distinciones de gusto y calidad. Algo parecido se presenta en el dibujo Sin título (1991) que ostenta el nombre del grupo glam español Locomía; un póster recreado con el pulso del rayón de un niño que da sus primeros pasos por los lápices. La fascinación del artista por estas personalidades ejemplifica las afinidades y contagios entre el camp y la cultura fan, en la cual niños, adolescentes y adultos pueden entrar en alianza con lo diferente. Así, Pombo despliega un yo artístico excesivamente autorreferencial que hace que la distancia entre el admirado y el admirador se acorte tanto por la imaginación como por la intimidad exhibida.

En otras obras, el artista propone un conjunto de imágenes que se desvían de las conductas sexuales normadas y los relatos de la felicidad relacionados con los marcadores lineales de la vida burguesa (nacer, casarse, reproducirse y morir). En el dibujo Sin título (1994) aparecen dos personajes característicos del artista (payasescos, con rasgos animales, originarios del cómic y con una fisonomía similar a su propio cuerpo), uno divertido y otro triste, pero sosteniendo su pene y eyaculando mientras dice: "Estoy más cansado de mis sueños que de la vida".

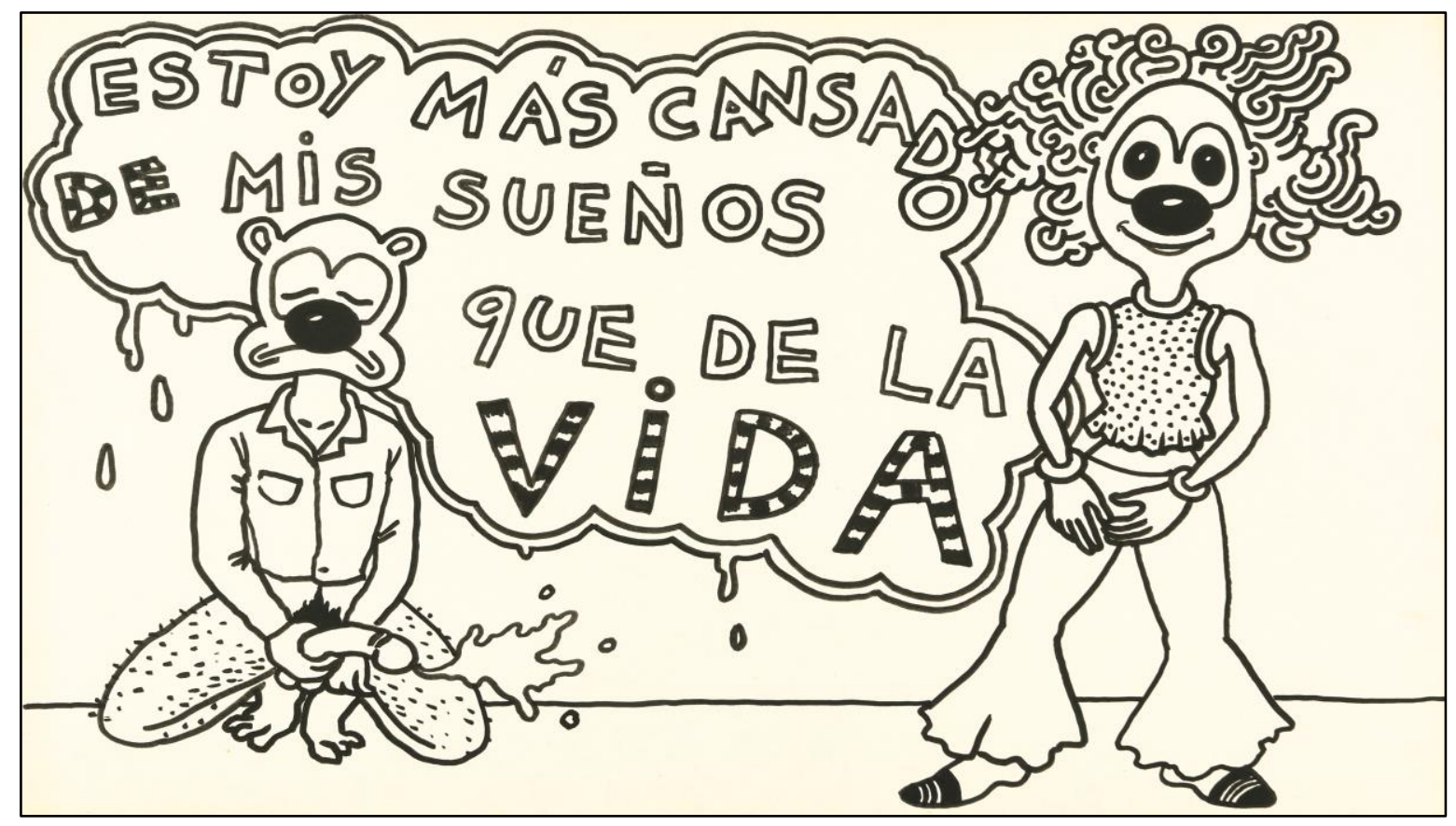

Marcelo Pombo, Sin título, 1994.

La masturbación no solo es un momento placentero y cotidiano que da lugar a numerosas fantasías, sino también una forma de autosustentabilidad que, incluso, puede prescindir del contacto con otros cuerpos y generar momentos de goce personal sin el imperativo de la compañía. Pombo pareciera estar cansado de esto, sin embargo, no atina a salirse de su propia 
zona de confort que, a la vista de otros, puede resultar precaria, pero que desde el enfoque de este trabajo es central para pensar distintos modos de experimentar el espacio, el tiempo y la corporalidad. Estas mismas coordenadas, que incluso apelan a los afectos desprestigiados por la racionalidad instrumental, se observan en una composición de la serie Dibujos de Puerto Madryn (1995). En ella dos payasos tristes y una joven algo hippie sostienen un cartel que dice "Soy una negra triste", más abajo, hacia un extremo y a modo de epígrafe catártico, se presenta la siguiente leyenda: "y no quiero hacer caras tristes sino cosas alegres y lindas pero soy una negra tonta, confundida, triste y de mal gusto que nunca tuvo un negro y ahora se quedó sola y triste y un poco loca". A través del drama exagerado y melancólico, Pombo juega a ser "otra", casi literaria, con la cual fraterniza en los márgenes. Si bien estas últimas características también conforman las representaciones culturales más estereotipadas de las disidencias sexuales, el artista se las apropia y se afirma en el sentido opuesto a un tipo de identidad gay, blanca y exitosa.

Desprovistas de contenidos sexuales de alto voltaje, las imágenes autobiográficas y las representaciones ficcionales también adquieren relevancia en Fernanda Laguna. No obstante, en la artista toman cauce en geometrías sentimentales, diarios íntimos, anotadores y láminas creadas con cartulinas, maderas y telas en las que pinta, pega stickers y recortes de revistas e incorpora materiales que se han vuelto escolares, a partir de la educación artística, como algodón, lana, cartón y ramitas. Sus obras hacen de lo desparejo una política visual, en algunas se observa un aprendizaje constante y en otras una fijación caprichosa por procedimientos que le resultan fáciles para la inmediatez de su verborragia. Laguna tampoco es una artista profesionalizada y su presencia alterna entre diferentes roles, como el de escritora (bajo el seudónimo Dalia Rosetti) y gestora de proyectos colectivos, como la galería de arte y editorial Belleza y Felicidad ${ }^{16}$ — fundada junto a Cecilia Pavón - y el taller de arte Belleza y Felicidad en Villa Fiorito (2003). Tanto en sus primeras exposiciones en la Galería del Rojas como en otras series posteriores, realizadas entre 1999 y 2001, la artista presenta un imaginario en el cual el amor desafiante y errático, la amistad, las relaciones casuales y caprichosas y la incertidumbre de crecer parecieran articular una red afectiva que, a la vez, es estética. Al principio, es posible observar que Laguna concibe su producción como la decoración de un cuarto de chicas, donde el retrato acaramelado de Luis Miguel en la portada del disco Aries (1994) se encuentra al lado de una Blancanieves coloreada y delineada con brillantina, Princesa (1994), que a su vez acompaña a otra menos cándida de larga cabellera y jeans ajustados, La chica más linda del mundo (1994). Respecto de estas obras, en un breve texto curatorial, Gumier Maier recuerda su propio paso por los talleres artísticos del barrio y señala: "Cuando recibí la carpeta de Fernanda Laguna aquella vieja inquietud infantil me volvió a embargar. Sería tal vez una de mis compañeras adultas de la Academia Asplanato, ¿hoy ya vieja gagá? La última foto reproducía un cuadro bucólico, un sol radiante, con la leyenda 'Shakti Gawain'. Dije: Tenga la edad que tenga, ella tiene que exponer" ("Fernanda Laguna"). Si bien el tiempo comprobó que Laguna no era vieja y tampoco una outsider, las palabras del curador -inscripto en

${ }^{16}$ Belleza y Felicidad fue creada en 1999 de manera autogestiva, hasta el 2007, año en que cerró sus puertas, dio lugar a la venta de obras y la edición y circulación publicaciones alternativas, exposiciones, lecturas de poesía, talleres y conciertos, véase Palmeiro (2011). 
la actitud irreverente de hacer arte con lo que haya y como se pueda- nos permiten pensar, una vez más, las subjetivaciones de estos artistas a través de esferas contrapúblicas, cadenas de relaciones que dan forma a sus programas de influencias anónimas o hipervisibles, apropiaciones, técnicas relegadas, materiales domésticos, micropolíticas y afectos que tuercen no solo la noción de valor artístico, sino también la figura del artista que aborda gestas heroicas y traumas universales.

Hacia finales de los años noventa y principios de los dos mil, las obras de Laguna resultan más compulsivas, su resolución es rápida, las palabras y las frases comienzan a adquirir importancia, funcionan como obras inacabadas, con mensajes cómplices, amorosos, tristes, caóticos y dubitativos; anteceden su labor como escritora dentro de las coordenadas que caracterizan, en un contexto de crisis, las formas de producción literaria en espacios como Belleza y Felicidad. En concordancia con Cecilia Palmeiro, quien retoma el concepto Paula

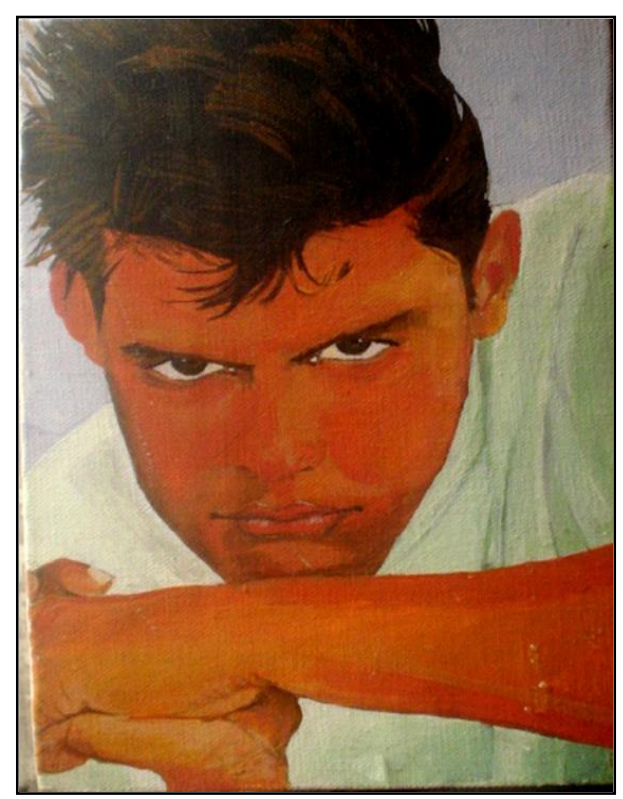

Fernanda Laguna, Luis Miguel, 1994. Sibilia de "homo tecnológico, subjetividad alterdirigida que se construye en la exhibición exterior" (166), es posible señalar que las imágenes construidas por Laguna, al igual que sus textos y los de otrxs autorxs como Washington Cucurto, Cecilia Pavón y Gabriela Bejerman, dan cuenta un tipo de escritura éxtima, hacia afuera y de superficie. Una fuerte desinhibición al momento de expresar las emociones mediante formas promiscuas de circulación de lo personal que anticipa el lenguaje desinhibido de la Internet. Obras confeccionadas en cartulinas con recortes y manchas de témperas como No soy celosa (1999) nos introducen en una historia de amor complicada por medio de frases como "Vos, ella y yo", "Soy celosa" y "Dame bola", lo mismo se reitera en No tenés equipo (2000) a partir de oraciones como "You only tell me you love me when you are drunk" [Solo me decís que me amás cuando estás borracho/a], tema del dúo pop electrónico Pet Shop Boys. Además de estos poemas visuales y adolescentes, también hay

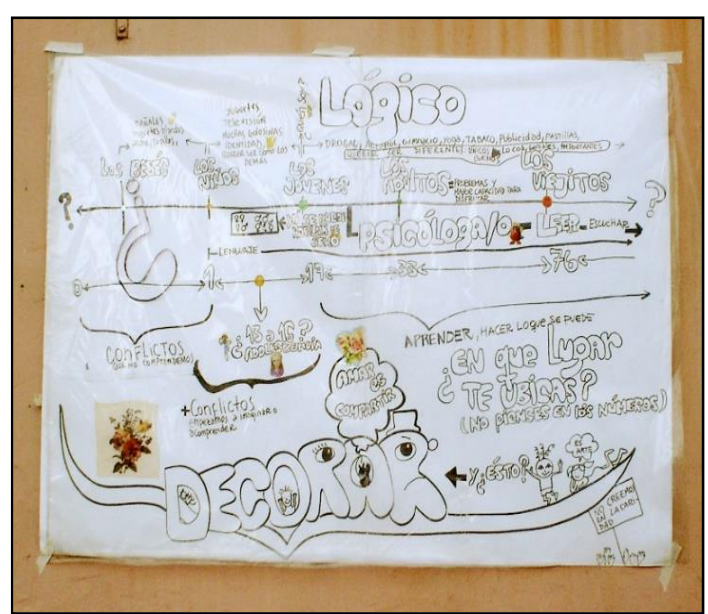

Fernanda Laguna, Gráfico 1, 2001. gráficos similares a los realizados en las escuelas secundarias pero repletos de información y dudas. Como por ejemplo Gráfico 1 (2001), en el cual la artista desarrolla sus conflictos existenciales en una línea del tiempo que va desde el nacimiento hasta la vejez $y$, a través de comentarios e información disgregada, asigna a cada etapa comportamientos, costumbres y problemas emocionales específicos. Sin embargo, el movimiento de esta línea no es evolutivo, sino que avanza y retrocede, las secuencias se solapan y desorganizan los marcadores temporales de la vida en su formato más instrumental, ya que por medio de flechas estos períodos comparten algunoshábitos con 
el anterior y el posterior, tal es el caso de "los jóvenes" quienes pueden "querer ser como los demás", al igual que "los niños" y también consumir "drogas, alcohol, gimnasio, yoga, tabaco, publicidad, pastillas" como "los adultos".

En otras obras, al igual que en su literatura, Laguna se desprende de las identidades sexuales fijas y transita sin ningún mote por diferentes amoríos. Estas referencias, en las que prima la experiencia o ingreso intempestivo de lo real, se observan en algunas de sus obras. Diarios abiertos o pequeños altares de placard, entre ellos Sin título (1999), presentan frases como "Llorar me hace bien

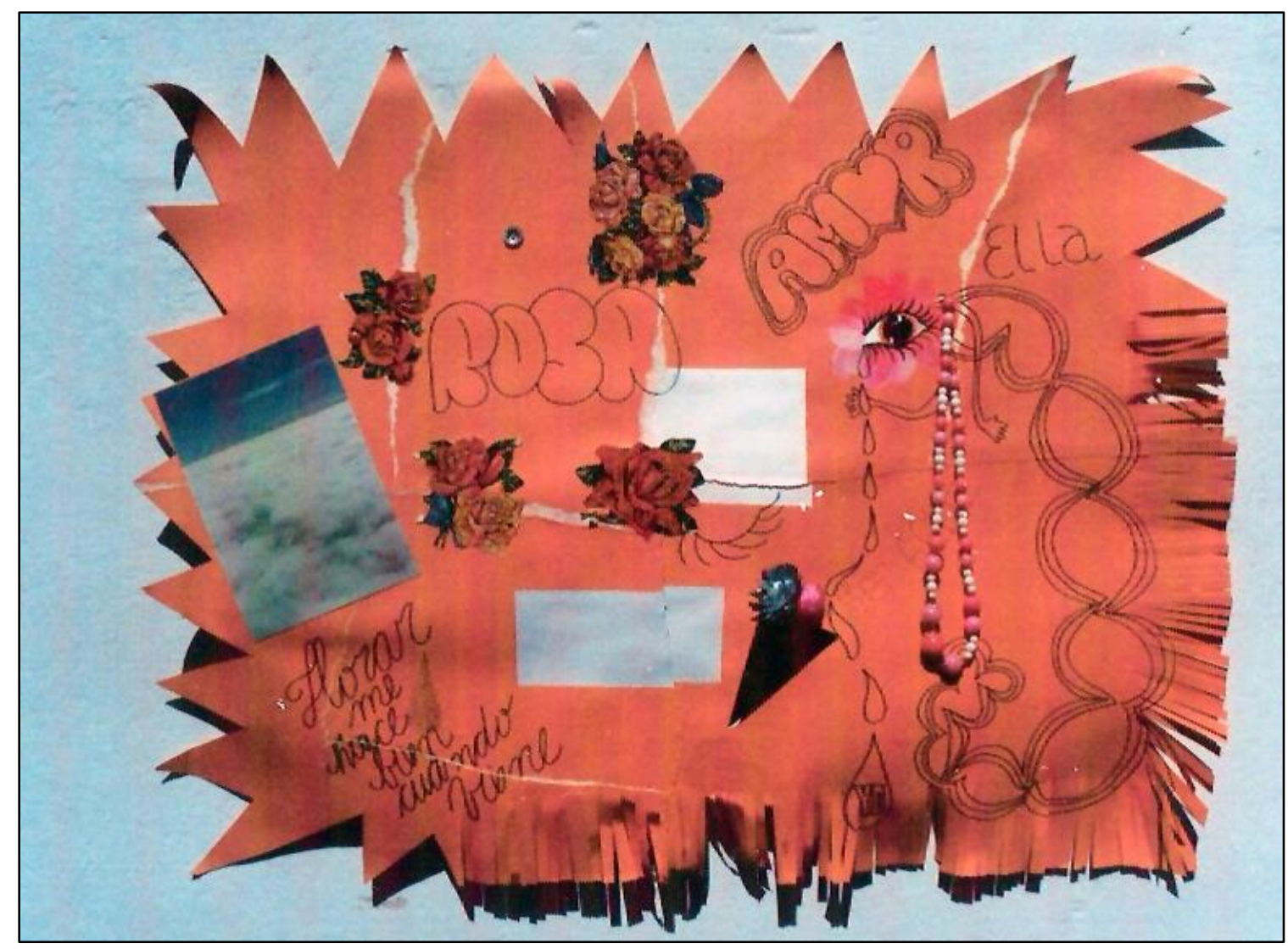

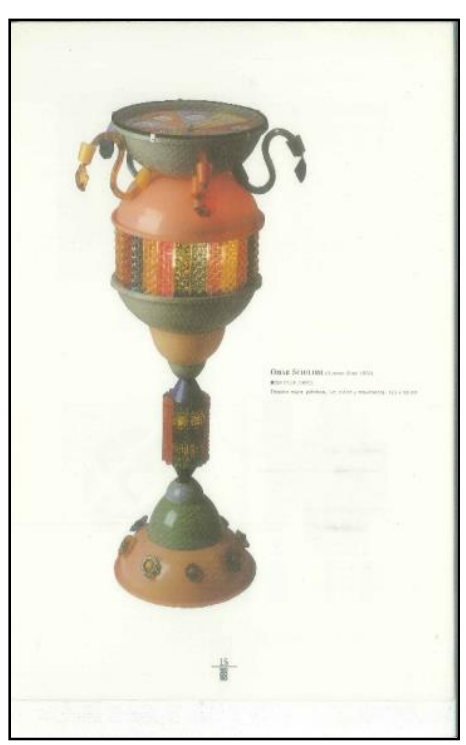

Omar Schiliro, Sin título, 1993.

Fernanda Laguna, Sin título, 1999.

cuando viene", "Vos y yo", "¿Quién me gusta?" o palabras como "rosa", "amor", "beso" y los pronombres "él" y "ella". A esto le suma recortes de rosas y nubes, sus típicos corazones humanizados, collares, dijes y otros objetos que se atesoran para evocar estados de enamoramiento, tristezas, obsesiones y amistades.

Si bien las obras de Omar Schiliro parecieran ser indescifrables, pensarlas desde esta línea trabajo permite ahondar en sus condiciones de posibilidad como artista. $D j$ en los tempranos ochenta $y$, más adelante, bijoutier de ferias y boutiques de ropa, la trayectoria de Schiliro es una de las más outsider en las genealogías del Rojas, ya que tanto los oficios que aprendió como su producción artística fueron un 
modo de supervivencia a la pobreza y al sida. En 1991 recibió su diagnóstico VIH positivo y hasta su muerte, en 1994, produjo de manera frenética objetos y esculturas realizadas con recipientes de plástico de uso doméstico como tapers y palanganas, caireles, perlas falsas, gemas y luces. Un tipo de manualidad barroca y artificial que reformula lo insignificante al trabajar sobre la belleza de lo trivial para el ojo cotidiano. Materiales baratos, presentes en los contenedores de una economía de libre mercado como la de los años noventa, de colores chillones y texturas tersas, fueron montados y combinados con otros más antiguos para conformar obras que se acercan al trofeo, el juguete, la luminaria y los cálices de una religión misteriosa que convoca a un ritual sostenido en la oposición entre el camp y lo bello, entre el arte y la artesanía, entre el esplendor de lo seriado y el culto a lo único. David Halperin sostiene que "el rol del camp es perforar el aliento, solemne, tediosamente monótono, del culto a la belleza" (207). En este sentido podríamos decir que la producción de Schiliro tensiona los límites de la belleza excluyente y cultura popular; una operación doméstica propia de las personas que habitan un mundo estético y político donde no hay relaciones supeditadas por jerarquías culturales.

Para volver a situar a Schiliro en este entramado de afectos, posicionamientos artísticos y micropolíticas que anclan en lo infantil, es necesario detenernos de manera detallada en algunas de sus obras, ya que en su caso constituyen un lugar carente de drama (no de trauma), una etapa de juego y refugio, evasiva de la tristeza. Según el relato de Gumier Maier, quien fue pareja de Schiliro, el artista era fan del parque de diversiones Italpark, de las casas que venden lámparas y de películas de ciencia ficción como El ladrón de Bagdad (1924), Barbarella (1968) y Willy Wonka y la fábrica de chocolate (1971); ${ }^{17}$ vale decir que un hilo común se presenta en este listado de

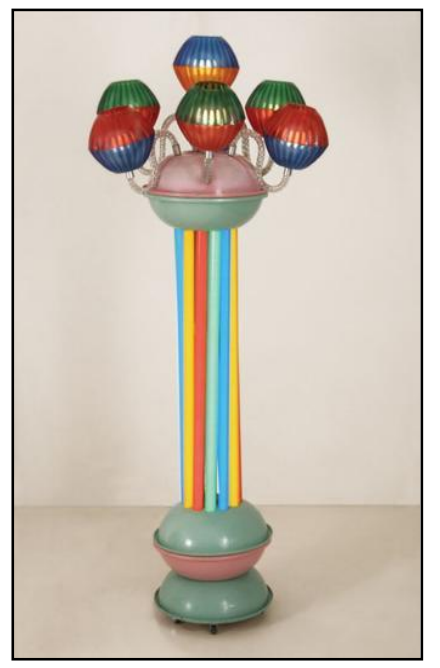

Omar Schiliro, Batato te entiendo, 1993. referencias: escenografías estrambóticas y mundos de ensueño. Estos espacios, según plantea Michel Foucault, funcionan como heterotopías, es decir, como instancias paralelas y alternativas por fuera de lo hegemónico, donde los significados y las relaciones son múltiples al generarse un espacio otro. La apelación artística a la infancia puede ser entendida como una heterotopía y como ese impulso queer que hace a las utopías concretas y extáticas. ${ }^{18}$ Obras como Amor (1992), una estructura similar a una glorieta de plaza que ampara a dos muñequitas agarradas de la mano sobre una cajita musical y Sin título (1993), que en su extremo superior porta una ruleta de juguete donde las posibilidades del azar son siempre buenas como: "viajecito placentero", "comidita rica", "el trabajito liviano", etc., no solo presentan formas del amor y el bienestar sin muchas pretensiones, sino que tratan de compensar la ausencia de una realidad más favorable por otra más alegre.

17 Entrevista personal con Jorge Gumier Mamier (16 de enero de 2016).

${ }^{18}$ Muñoz (Cruising Utopia) se apoya en las ideas desarrolladas por Ernst Bloch, en The Principle of Hope (19541959) y Literary Essays (1998), para sostener que lo queer-utópico es ese impulso que encontramos en las experiencias estéticas —wish-landscapes (Bloch)—, utopías concretas y extáticas que interrumpen la temporalidad lineal que articula tanto la hetero como la homonorma. 
Pero, ¿cómo se transforman estas temporalidades frente a la irrupción del sida? ¿Qué sentidos adquieren estas imágenes cuando el futuro se desvanece? En estos años, el sida instaló de manera global otro tiempo, ya sea por la llegada de una enfermedad "extraña" que impuso un límite muy próximo a la vida o por su vuelta crónica que propició una sobrevida farmacológica. A diferencia del accionar de colectivos como Act Up, ${ }^{19}$ en Argentina la mayoría de los artistas no llevaron a cabo proyectos donde su condición de VIH positivo se pusiera de manifiesto, y tampoco hicieron pública su enfermedad, seguramente por los efectos de la injuria en estas latitudes (Gumier Maier, "Sin título"). Por tal motivo, las resonancias en las artes visuales son escasas, a excepción de las imágenes creadas por artistas como Liliana Maresca (1951-1994), Alejandro Kuropatwa (1956-2003) y Feliciano Centurión (1962-1996) y algunas exposiciones realizadas de manera aislada. Gumier Maier habla de un "engañoso repliegue" (7), es decir que los artistas optaron por generar "ceremonias intangibles, mínimas y reiteradas como un rezo" (12) en la intimidad de su propia comunidad. En estas ceremonias encontramos micropolíticas corporales que proporcionaron claves sobre la gestión biopolítica de la vida, diarios de supervivencia en los cuales la historia clínica migró suavemente a imágenes y obras colectivas que trazaron espacios y tiempos compartidos. Dentro de estas respuestas al virus, las obras de Schiliro son rituales con guiños amorosos en torno al cuidado y homenajes íntimos entre amigos.

Vale como ejemplos la obra Batato te entiendo (1993), que desde el título hace alusión al artista Batato Barea —fallecido a causa de sida en 1991 - o el tríptico Salud, Dinero y Amor (1993), un conjunto de talismanes para la buena vida en el cual "Salud" tiene la forma de copón y porta un sorbete relleno con perlas que funcionan como "píldoras sanadoras" o "cápsulas de energía" amuleto que Feliciano Centurión tuvo en su hogar para contrarrestar el deterioro de su cuerpo- ${ }^{20}$ Intentar estar juntos y crear las situaciones necesarias para eso, desobedecer y tensar con el propio cuerpo la fuerza moldeadora de la injuria y el llamado al aislamiento y hacer del diagnóstico un material poético para transitar el trauma, son algunas de las estrategias que encontramos en este grupo de artistas.

\section{Consideraciones finales}

Al adentrarse en el campo artístico de los años noventa se observan distintos procesos de subjetivación gestados entre finales de la dictadura militar y la transición democrática, también se advierten alianzas y disputas polarizantes en torno a la legitimidad artística y cierta dificultad de leer por parte de la crítica de arte que tendió a licuar la potencialidad de los artistas nucleados por

${ }^{19}$ Act Up (AIDS Coalition to Unleash Power) fue un grupo de acción directa creado en 1987, situado en Nueva York y luego extendido a otras ciudades de Estados Unidos. Su objetivo principal fue reclamar de manera inmediata políticas y legislaciones en relación al VIH-sida, tales como asistencia médica gratuita, pruebas de tratamientos farmacológicos, ayuda económica y contención a los portadores. Su activismo se se caracterizó por intervenciones mediáticas, manifestaciones callejeras y escraches a instituciones del poder gubernamental, acompañadas por el desarrollo de imágenes y acciones performáticas de alto impacto visual.

${ }^{20}$ Entrevista personal con Jorge Gumier Maier, marzo de 2013. 
Gumier Maier en la Galería del Rojas. En una coyuntura marcada por la extranjería acrítica y la precarización de la vida —entre la flexibilización laboral, el sida y la profesionalización exacerbada-, la opción por prácticas desaceleradas como el trabajo artesanal y las manualidades, interrupciones como las que genera el collage y la demora a la que invita el dibujo como experiencia que lentifica y sitúa las cosas en otro orden, no solo proponen una temporalidad queer con respecto al carácter transitivo del canon moderno y su insistencia en la racionalidad instrumental, sino también una salida a las formas estandarizadas del arte contemporáneo global y su producción acelerada de signos estéticos. Esto no significó un localismo militante por parte de Gumier Maier y los artistas, sino más bien un repliegue táctico, contraproductivo para el carácter urgente y expansivo de las subjetivaciones en tiempos neoliberales.

La apropiación de códigos inscriptos dentro del camp, la devoción por lo artificial y lo degradado, la apelación a materiales y tareas subordinadas en el sistema sexo-género y la construcción de un yo artístico que desafía la disciplina y el autocontrol como también el modelo liberal y burgués de los públicos dominantes, funcionan como acciones que desajustan la linealidad que regula tanto el historicismo como la vida en su condición productiva. En este sentido, Marcelo Pombo, Fernanda Laguna y Omar Schiliro, a la vez que apostaran por lo infantil y adolescente, idearon un impulso creativo conformado por modos de sentir agenciados en el fracaso, el ridículo, el cansancio, el dilema amoroso, las fantasías y otros afectos que han adquirido valor a través de las teorías posidentitarias y el giro afectivo. En ellos encontramos imágenes que habitan formas antirracionales y escapan de la vida adulta, ya que han hecho de su producción artística un tipo de imaginación que descalza las narrativas del éxito.

\section{Referencias bibliográficas}

Ameijeiras, Hernán. "Un debate sobre las características del supuesto 'arte light". Liliana Maresca, documentos. Comp. Gachi Hasper. Buenos Aires: Libros del Rojas-Universidad de Buenos Aires, 2006. 121-24. Impreso.

Basualdo, Eduardo. "Las reformas estructurales y el Plan de Convertibilidad durante la década del noventa. El auge y la crisis de la valorización financiera". Realidad económica 200 (2003: 4283). Web. 3 oct. 2016 <https://goo.gl/ZpRsxg>.

Cuello, Nicolás y Francisco Lemus. "'De cómo ser una verdadera loca'. Grupo de Acción Gay y la revista Sodoma como geografías ficcionales de la utopía marica". Badebec 6.11 (2016): 250 75. Web. 3 oct. 2016 <https://goo.gl/FhsVhc>.

Deleuze, Gilles y Félix Guattari. Mil mesetas. Capitalismo y esquizofrenia. Trad. José Vázquez Pérez. Valencia: Pre-Textos, 2015. Impreso.

Kafka. Por una literatura menor. Trad. Jorge Aguilar Mora. Ciudad de México: Ediciones Era, 1990. Impreso.

Foucault Michel. "Of Other Spaces, Heterotopías". Architecture, Mouvement, Continuité 5 (1984): 46 49. Impreso. 
Fraser, Nancy. "Rethinking the Public Sphere. A contribution to the Critique of Actually Existing Democracy". Habermas and the Public Sphere. Comp. Craig Calhoun. Cambridge: MIT, 1992. 109-42. Impreso.

Francica, Cynthia. "Lo queer infantil en la literatura de Belleza y Felicidad". Pretérito indefinido. Afectos y emociones en las aproximaciones al pasado. Eds. Cecilia Macón y Mariela Solana. Buenos Aires: Título, 2015. 157-83. Impreso.

Freeman Elizabeth. Time binds. Queer temporalities, Queer Histories. Durham: Duke UP, 2010. Impreso.

Giorgi, Gabriel. Formas comunes. Animalidad, cultura, biopolítica. Buenos Aires: Eterna Cadencia, 2014. Impreso.

González, Valeria y Máximo Jacoby. Como el amor. Polarizaciones y aperturas en el campo artístico en la Argentina. 1989-2009. Buenos Aires: Libros del Rojas-Universidad de Buenos AiresCCEBA, 2009. Impreso.

Gumier Maier, Jorge. "Sin título". Feliciano Centurión. Últimas obras. (cat. exp.). Asunción: Centro Cultural de España "Juan de Salazar", 1999. 6-12. Impreso.

. "El tao del en arte". El tao del arte (cat. exp.). Buenos Aires : Centro Cultural Rector Ricardo Rojas-Centro Cultural Recoleta, 1997. 7-14. Impreso.

. "Abajo el trabajo". Ramona 9-10 (2000-2001): 22-23. Web. 3 oct 2016 <http://70.32.114.117/gsdl/collect/revista/revistas/ramona9-10.pdf >.

. "Fernanda Laguna". Fernanda Laguna: pinturas y objetos (cat. exp.). Buenos Aires: Centro

Cultural Rector Ricardo Rojas, 1994. Impreso.

-------. "Avatares del arte". La hoja del Rojas 11 (1989). Impreso.

Halberstam, Judith. In a Queer Time and Space. Transgender Bodies, Subcultural Lives. New YorkLondon: New York UP, 2005. Impreso.

Halperin, David. How to be gay. Cambridge: Harvard UP, 2012. Impreso.

Huyssen, Andreas. Después de la gran división. Modernismo, cultura de masas, posmodernismo. Trad. Pablo Gianera. Buenos Aires: Adriana Hidalgo, 2002. Impreso.

Katzenstein, Inés. "Acá lejos. Arte en Buenos Aires durante los años noventa". Ramona 37 (2003): 547. Web. 3 oct. 2016 <https://goo.gl/7wLRbL>.

López Anaya, Jorge. "El absurdo y la ficción en una notable muestra". La Nación. 1 ago. 1992. Impreso.

Macón, Cecilia. "Sentimus ergo sumus. El surgimiento del giro afectivo y su impacto sobre la filosofía política". Revista Latinoamericana de Filosofía Política 6.2 (2013): 1-32. Impreso.

Molloy, Sylvia. Poses de fin de siglo. Desbordes del género en la modernidad. Buenos Aires: Eterna Cadencia, 2012. Impreso.

Muñoz, José Esteban. Cruising Utopia. The Then and There of Queer Futurity. New York-London: New York UP, 2009. Impreso.

Desidentifications. Queers of Color and the Performance of Politics. Minneapolis: $U$ of Minnesota P, 1999. Impreso.

Perlongher Néstor. Prosa plebeya. Buenos Aires: Excursiones, 2013. Impreso. 
Palmeiro, Cecilia. Desbunde y felicidad. De la Cartonera a Perlongher. Buenos Aires: Título, 2011. Impreso.

Rosa, María Laura. "Cuando es la intimidad es política. Arte y homosexualidad en el Centro Cultural Ricardo Rojas durante los años noventa". Relaso 5 (2015): 135-149. Web. oct. 2016 $<$ https://goo.gl/s9pmZr>.

Usubiaga, Viviana. Imágenes inestables: artes visuales, dictadura y democracia en Argentina. Buenos Aires: Edhasa, 2012. Impreso.

Pineau, Natalia. "Espacios de exhibición durante los años noventa en Buenos Aires y la formación de una nueva escena artística". Travesías de la imagen. Historia de las artes visuales en Argentina. Vol.1. Eds. María Isabel Baldasarre y Silvia Dolinko. Buenos Aires: EDUNTREFCAIA, 2012.607-35. Impreso.

Preciado, Paul B. "Multitudes queer. Notas para una política de los 'anormales'". Nombres Revista de Filosofía 19 (2005). Web. 3 oct. 2016 <https://goo.gl/C5NdpY>.

Ramos Mejía, José María. Las multitudes argentinas. Buenos Aires: Fondo Nacional de las Artes, 2012. Impreso.

Restany, Pierre. "Arte guarango para la argentina de Menem". Lápiz. Revista internacional del arte 116 (1995): 50-55. Impreso.

Svampa, Maristella. La sociedad excluyente. La Argentina bajo el signo neoliberal. Buenos Aires: Taurus, 2003. Impreso.

Sennett, Richard. El artesano. Trad. Marco Aurelio Galmarini. Barcelona: Anagrama, 2009. Impreso.

Warner, Michael. Público, públicos, contrapúblicos. México D.F.: Fondo de Cultura Económica, 2012. Impreso.

Wortman, Ana. "Estudios y otras prácticas intelectuales latinoamericanas en cultura y poder". AA.VV. Estudios y otras prácticas intelectuales latinoamericanas en cultura y poder. Buenos Aires: CLACSO, 2002.1-16. Impreso. 